UDC 342.9

DOI https://doi.org/10.32836/2521-6473-2018-2-50-54

O. O. Hubanov, Candidate of Juridical Sciences, Leading Lawyer of the Programme on Adoption of Ukrainian Legislation to EU Law of Faculty of Law, Taras Shevechenko National University of Kyiv

\title{
NOTIONS OF THE LEGAL RESPONSIBILITY OF EUROPEAN PUBLIC SERVANTS: TOPICAL ISSUES OF LAW ENFORCEMENT
}

The author analyzes whether there is a balanced system of the legal principles of the liability of the public officials in the domestic legislation of Ukraine which can be used as the basis for further statute regulations improvement. The author also compares those principles which are indicated by the legal doctrine in Ukraine with the principles established by the European law. Presenting specific examples, the author shows how European principles are overlooked by the domestic legislation of Ukraine, and, therefore, comes to the conclusion that there is a pressing need to work on the concept of the legal liability of the public servants, which can be later used as a basis for a complex reform of the sector.

Key words: principles, legal liability, public officials, public service.

О. О. Губанов. Принципи юридичної відповідальності публічних службовців у краӥнах Європейського Союзу

Автор досліджує питання наявності у вітчизняному законодавстві чіткої Й узгодженої системи принципів юридичної відповідальності публічних службовиів, яка могла б служсити підставою для встановлення належного правового регулювання зазначеного інституту. Розглянуто панівні в юридичній науиі уявлення про інститут принципів юридичної відповідальності публічних службовиів, здійснено порівняння наукових принципів із принципами, встановленими нормативно-правовими актами Європейського Союзу. На конкретних прикладах автор демонструє ігнорування вітчизняним законодавством ухвалених Європейським співтовариством принципів. Автор дійшов висновку про необхідність розроблення комплексної конщепиії юридичної відповідальності публічних службовиів в Україні.

Ключові слова: приниипи, юридична відповідальність, публічні службовиі, публічна служба.

Reforming public service in Ukraine, as a majority of other processes for the improvement of domestic legal system (judicial reform, administrative reform etc.), is aimed, first of all, at realizing the European integration policy of Ukraine.

Moreover, the integration, which is a guide for Ukraine now, involves not only a free movement of goods, people and capital, but also the creation of a similar legal space.

Thus, if Ukraine joins the European Union (hereinafter referred to as the EU) there will be the need of a profound modification of the domestic legislation in compliance with the legislation of European community. In this regard, non-adapted legislation may be significantly changed that can cause an imbalance of relevant parts of the domestic legal system (within the framework of this research, it is public service system).

In order to prevent this situation, public service reform as a whole and the institution of legal responsibility of public servants, in particular, requires taking into account the experience of European countries in advance in order to implement standards gradually without violating the functionality of a system in general.

However, it is impossible to find the right way, if the ultimate goal is not clear.

(C) O. O. Hubanov, 2018 
According to our belief, the purpose of reforming of legal liability of public servants (civil, criminal, administrative and disciplinary) should include several clear, effective and harmonized principles.

Consequently, the article's purpose is an analysis of the experience of EU countries in regulation of legal liability of public servants in terms of background principles, which the European community relies on when elaborating particular legal regulations, and presentation of their system.

Researches on the principles of legal liability in general, as well as on some of them and key features common to such principles, were carried out by a number of scholars, including T. Bazylov, O. Bolsunova, D. Lypynskyi, O. Maksymiuk, R. Khachaturov and others.

In order to achieve the article's purpose it is necessary to cover three topical issues:

1. What principles of legal liability of public servants do act in Ukraine?

2. What principles of legal liability of public servants do act in EU countries and are common for them?

3. Do the principles of legal liability of public servants, according to Ukrainian legislation, coincide with those that are implemented in EU countries? Can the principles of legal liability of public servants of EU countries be borrowed to the national legislation through amending, or there are significant differences that need a profound modification of Ukrainian legislation?

To ensure the unity of concepts within this study the principles of legal responsibility are understood as the internal regularities of the availability of the institution of legal responsibility, the nonobservance of which inevitably deforms the institute and leads to an artificial mix with other law enforcement institutions [1, p. 30].

Developing this idea, we find it necessary to turn to O. Bolsunova [2, p. 49] who stated that the principles of legal liability are defined:

- as background principles and ideas of the functioning and realization of legal liability (functional aspect of the principles of legal liability);

- as conditions for bringing offenders to legal liability;

- as the main principles, which have a direct effect, and are applied to prevent the disregard for the rule of law and justice while bringing individuals to legal liability (value aspect of a legal liability).

In our opinion, the above characteristics also should be applied to the institution of legal liability of public servants, which is an integral part of the institution of legal liability as a whole.

Analyzing the achievements of domestic scholars, we can conclude that today legal science marks the following criteria, which correspond to the abovementioned features of legal liability of public servants:

1. Legality. It has double nature towards the liability of public servants:

- a public servant shall take responsibility if violates the provisions of p. 2 Art. 19 of the Constitution of Ukraine (neither on grounds or within powers, or in a manner that are stipulated by the Constitutions and Laws of Ukraine) [3];

- in addition, a subject which brings a public servants to legal liability shall actin accordance with the law, and in a manner and way which are consolidated by the law [4, p. 48-49].

2. Justice. Within the institution of legal liability of a public servant, this principle is defined as the compliance of responsibility with the severity of a violation. In other words, if the restriction of a particular right is permissible, the state may use not excessive but only necessary measures, which are clearly determined by objectives of legal regulation [5, p. 79].

3. Humanism (p. 2 Art. 28 of the Constitution of Ukraine states: nobody can be subjected to torturing, cruel, inhuman, or such that disrespects his dignity, treatment or punishment).

4. Timeliness is the necessity to bring an offender to liability during limited time of prescription, namely a time period, which is commensurate with a violation degree, since the moment of its 
commission. This principle is implemented in the legislation of Ukraine through terms for imposing disciplinary action, terms for limitation in civil law and terms for imposing administrative penalty.

5. Presumption of innocence. We propose to understand it not only in a criminal aspect, as stated in Art. 62 of the Constitution of Ukraine, but also extending its effect to any legal responsibility of a public servant, as to assume that a public servant is unfair without proving this assumption by admissible evidence is non-compliance with Art. 21 of the Constitution of Ukraine, according to which all people are free and equal in their dignity and rights [3].

Thus, in relation to public servants, the assumption of good faith of a public servant is fair, until the contrary is not proved regardless of the type of liability, except for civil one.

6. Prohibition to bring to responsibility for the same violation two or more times. We also propose to expand comprehension of p. 1 Art. 61 of the Constitution of Ukraine in such a manner that a person cannot be brought to liability of different type, except the obligation to compensate for damage that is caused by offense.

7. Individualization of responsibilities. Thus, according to p. 2 Art. 61 of the Constitution, the legal liability of a person has an individual nature. Taking into account the importance to ensure guarantees of the rights of public servants, the specified principle becomes extremely topical, in particular, due to lustrations measures. This principle is agreed with the principles of civil service set in par. 10 p. 1 Art. 4 the Law of Ukraine "On Civil Service", according to which civil service is carried out in compliance with stability principle - appointments of civil servants for an indefinite period, except for statutory cases, independence of civil service personnel from shifts in a political leadership of the state and government bodies.

At the same time, guided by the criteria for the principles of legal liability of public servants that are proposed in this paper, we should disagree with the opinion of some scholars regarding the acceptance of the following ones as principles of legal liability:

1. Substantiation principle. Thus, the science has an idea that the essence of substantiation principle consists in a detailed study of the circumstances of a case over disciplinary offense, according to its results the fact of commitment of such misdemeanor should be clearly documented by virtue of acts, its elements must be established, and a penalty is applied taking into account the committed act and identity of a guilty person [4, p. 49].

This principle is a procedural embodiment of the principles of presumption of innocence and legality which set the requirements for a fair procedure in bringing a person to legal liability. At the same time, the rule of substantiation can be interpreted in a quite broad sense (for example, reasonableness in terms of achieving a certain goal) that does not allow it to be considered as a legal principle in connection with its uncertainty.

2. Principle of inevitability. Unavoidability of responsibility is, most likely, a result of law enforcement activities and coefficient of efficiency of regulatory and law enforcement bodies. At the same time, the principle as a fundamental basis for legal regulation:

- completely coincides with a principle of commensurability towards a

tangible part of legal liability (in case of violation there should be a commensurable liability);

- cannot by applied as a basis for procedural regulation as it leads to a prosecutorial bias, which contradicts presumption of innocence.

3. Accuracy and comprehensibility. Thus, according to some scholars, a formal determinacy of norms of rights restriction implies their sufficient accuracy, which ensures their proper comprehension and application. In the context of admissibility of legal restrictions it is stipulated a legal determinacy of subjective possibilities (rights, freedoms and obligations) of a person. Any legal right requires that its meaning and volume are clarified, content and belonging of each correlative obligation are clearly formulated, as well as permissible limits of restrictions are specified [5, p. 77]. 
Authors totally agree with the requirements, which are involved by the principle, however, we think that the mentioned definition is one of the regulations for legitimacy principle, but not an individual principle typical for legal liability of public servants.

Thus, the application of criteria, which are developed by juridical science, for determination of legal liability principle permits to distinguish the principles of legal liability of public servants as follows:

a) legitimacy;

b) justice;

c) humanism;

d) timeliness;

e) presumption of innocence;

f) prohibition to bring to responsibility for the same violation two or more times;

g) individualization of responsibility.

In relation to the second question, it is necessary to study the principles that have not been reflected in the list but act as background principles in the lawmaking activity of EU countries when deciding on the legal liability of public servants.

In order to avoid the risk of relying on a country's experience that is not in line with the common European experience, we consider it is expedient to refer to the common European Union legislation.

The main international document of the European community defining the legal status of public servants is Recommendation № R (2000) 6 of the Committee of Ministers of the Council of Europe adopted on February 24, 2000 (hereinafter referred to as the Recommendation) [6].

This act, in addition to the general principles of public service, indicates that, at least, the following legal principles should be applied in relation to legal (in this case, disciplinary) liability of public servants:

a) availability of all rights that private individuals are empowered with together with the restrictions that are conditioned by public service and are minimum necessary for proper performance of the functions of public servants. At the same time, the restriction of rights must correspond to the purpose of official functions performance (par. 8 of the Recommendation);

b) non-discriminatory treatment for any reason;

c) liability for improper performance of official duties. At the same time, guarantees of a fair procedure should be provided during disciplinary proceedings(an open procedure with the right to access to legal aid which is established by the law).

When analysing the above principles, the attention should be paid to a fundamentally different approach that is used in EU countries regarding the liability of public servants.

Ukrainian principles of legal liability of public servants are the same with the principles of legal liability of any private person, but are specified on individual basis and independently of them, in EU countries another approach has been used - in general, the principles of liability of private individuals are applied, but with the differences common to public servants (par. 8 of the Recommendation) [6].

In our opinion, although the principle of non-discrimination is consolidated by the Constitution of Ukraine, but it is violated, in particular during performing lustration measures in relation to particular persons due to their post in a certain period of time, despite commission or non-commission of the offenses.

This principle was broken by the Law of Ukraine № 746-VII dated February 21, 2014 when amending Art. 365 of the Criminal Code of Ukraine, as when the amendments came into effect the excess of authority or official powers by a public servant, who is not an employee of a law enforce-

ISSN 2521-6473 
ment agency, does not entail a criminal liability even if it caused a significant damage to the rights and interests of third parties [7].

Consequently, one should conclude that the principle of non-discrimination and the principle of liability for breach of official duties are not implemented in Ukraine when exercising legal regulation of liability of public servants.

Based on the stated information, we believe it is essential:

a) to conduct an individual study on the nature of principles of legal liability of public servants in order to identify the features which permit:

- to outline such principles among other principles of legal regulation; structions;

- to separate efficiency results of regulatory and law enforcement agencies from legal in-

b) to develop a full-fledged system of principles of legal liability of public servants with an obligatory consideration of the principles of non-discrimination and mandatory liability of public servants for improper performance of official duties;

c) to implement a complex reformation of Ukrainian legislation in terms of legal liability of public servants on the ground of developed concept.

\section{References:}

1. Базылев Б. Юридическая ответственность: теоретические вопросы. Красноярск: Изд-во Красноярского университета, 1985. 213 с.

2. Болсунова О. Сутнісні засади принципів юридичної відповідальності. Часопис Київського університету права. 2010. № 4. С. 48-52.

3. Конституція України: Закон України від 28 червня 1996 р. № 254к/96-BP. URL: http://zakon3.rada.gov.ua/laws/show/254\%D0\%BA/96-\%D0\%B2\%D1\%80.

4. Дисциплінарно-деліктне право України: навч. посіб / Т. Аніщенко, Ю. Берлач, Д. Бондаренко та ін.; за заг. ред. Т. Коломоєць, В. Колпакова. К.: Ін Юре, 2016. 464 с.

5. Максимов И. Административные наказания. М.: Норма, 2009. 299 с.

6. Рекомендація Комітету Міністрів Ради Свропи № R (2000) 6 від 24 лютого 2000 p. URL: http://www.uni-speyer.de/files/de/Lehrstühle/Stelkens/Lehrveranstaltungen/EuVerwR_weitere\%20Materialien/Recommendation_No_R(2000)6.pdf.

7. Про внесення змін до Кримінального та Кримінального процесуального кодексів України щодо імплементації до національного законодавства положень статті 19 Конвенції ООН проти корупції: Закон України від 21 лютого 2014 р. № 746-VII. URL: http://zakon4.rada.gov.ua/laws/show/746-18. 